\title{
Organoleptic, Chemical and Microbiological Changes in European Eel (Anguilla anguilla L.) During Storage: Skinned vs. Unskinned Fish held at $2^{\circ} \mathrm{C}$ and $5^{\circ} \mathrm{C}$
}

E. McLean ${ }^{1 *}$, B. Rønsholdt ${ }^{2}$, R. Roesen Nørgaard², C. Kjølby Jensen ${ }^{2}$, L. Jacobsen ${ }^{3}$

${ }^{1 *}$ Virginia Polytechnic Institute and State University Aquaculture Center

Department of Fisheries and Wildlife Sciences, 156 Cheatham Hall, Blacksburg, VA 24061-0321 USA

E-mail: emclean@vt.edu

2 Aalborg University

Sohngaardsholmsvej 57

DK-9000 Aalborg, Denmark

${ }^{3}$ Heilsufrødiliga Starvsstovan

Debesartr $\varnothing \partial$,

FO-100 Tørshavn, Faeroe Islands

* Corresponding Author

\section{ABSTRACT}

Studies were undertaken to examine quality deterioration in stored skinned and unskinned fresh eels derived from a commercial recirculation facility. Fish samples were held at 2 and $5^{\circ} \mathrm{C}$ for 18 days and examined sensorially, chemically and microbiologically. Oil content of experimental animals averaged $39.1 \%$, that for dry matter was $47.8 \%$ and $12.1 \%$ and $0.69 \%$ for protein and ash content respectively. Trimethylamine-oxide (TMA-O) and trimethylamine (TMA) levels remained below detection

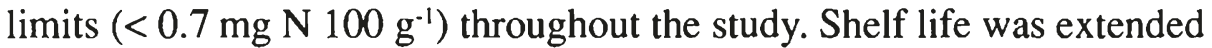
for both skinned and unskinned fish at the lowest temperature. By day 14 of the trial, differences $(P<0.05)$ were detected by sensorial evaluation for both temperatures evaluated and between skinned and unskinned animals. Increases $(\mathrm{P}<0.05)$ were detected for TVB-N throughout storage with fish held at $5^{\circ} \mathrm{C}$ expressing higher levels $(\mathrm{P}<0.05)$. Sample lipid oxidation increased throughout the study period. TBA was determined as a suitable variable for predicting overall impression of product quality. K1 value illustrated significant $\left(\mathrm{P}<0.0001 ; \mathrm{R}^{2} 0.72\right)$ polynomial correlation with overall impression. 


\section{INTRODUCTION}

European eel (Anguilla anguilla) production has expanded significantly over the last 15 years, with the sector experiencing a more than doubling in production from circa 4,500 metric tons in 1987 (Heinsbroek 1991) to 10,215 metric tons in 2001 (FEAP 2002). The major part of industry expansion has been achieved due to the development of intensive recirculation systems, together with an enhanced understanding of the nutritional and biological requirements of the species. Increased production however, has been accompanied by a decline in value, which has slumped by $42 \% \mathrm{kilo}^{-1}$ since 1995 (FEAP 2002). For the industry to remain viable, farmers must look towards further improvements in production efficiency and market diversification. At present, European eels are primarily used for the manufacture of value added semipreserved products which include smoked and jellied eels. More recently, European eels have been used for the production of kabayaki destined for Japan and European specialty markets (Bovbjerg 1999, Byrne 1999). However, surveys have indicated that Dutch, French, and German markets in particular, have significant demands for fresh eels, with farmed animals generally being favored by the consumer due to their thinner skin and higher fat levels (Fransu 1989, Globefish 1998).

The development of an expanded fresh eel market will demand an increased awareness of the shelf life of such products. Only one previous study has considered the spoilage characteristics of fresh eel (Rehbein and Hinz 1983) and these authors indicated a shelf life of approximately 16 days for ice-stored wild fish, derived from the Baltic Sea. After this period however, organoleptic spoilage of the raw material became pronounced. In contrast to cultivated eels, wild fish have a lower fat content (Lie et al. 1990). Hence, lipid oxidation processes may be more prominent in farmed eels than their wild counterparts (Hutlin 1992). Such a difference may alter the shelf life characteristics of aquacultured animals in terms of chemical, bacterial and organoleptic changes to the flesh. In order to examine this possibility, the present study explored quality changes to aquacultured eels derived from a commercial intensive recirculating system. Both unskinned and skinned animals were investigated since, in the latter, oxygen and spoilage organisms may penetrate into the flesh more readily, accelerating deterioration of the raw material. The shelf life of fresh eel was evaluated at temperatures mimicing those encountered in the retail chain. 


\section{Experimental}

\section{Animals}

Eels reared in a recirculating system at $25^{\circ} \mathrm{C}$ were purchased from a commercial supplier (Milbak Eel Farm, Sulsted, Denmark). Fish, which were presumably of mixed sex, ranged between 140 and $160 \mathrm{~g}$ in weight at the time of sampling. All animals were fed Ecoline 19 pellets (Biomar, Brande, Denmark) throughout the production period but were purged for 7 days prior to slaughter. Eels were killed, gutted and either left intact or skinned at the farm, before transportation to the laboratory. Approximately 1 hour elapsed between slaughter and storage.

\section{Storage and sensorial evaluations}

Skinned and unskinned fish were placed in individual plastic bags and stored at $2^{\circ} \mathrm{C}$ and $5^{\circ} \mathrm{C}\left(+0.1^{\circ}\right)$ for up to 18 days. At $0,5,10,14$ and 18 days, two eels from each treatment were evaluated microbiologically for $\mathrm{H}_{2} \mathrm{~S}$-producing spoilage, and total bacteria. Total volatile base nitrogen (TVB-N), lipid oxidation (thiobarbituric acid $\{$ TBA $\}$ ) and changes in flesh $\mathrm{pH}$ were also monitored. Sensory panels evaluated samples at 0,5 , 10,14 and 18 days for both temperatures employed.

\section{Analytical techniques}

\section{Sensory scheme and protocol development}

Prior to sensorial evaluation, a sensory scheme was developed for skinned and unskinned raw eels stored at $2^{\circ} \mathrm{C}$ for 23 days. At various time intervals, raw and cooked eels were examined for organoleptic characteristics. Odor, flavor and textural parameters were incorporated into a descriptive profiling sensory scheme (Table 1), with a subjective scale describing overall impression. The sensory panel was provided with an instruction sheet that presented definitions for each parameter considered (Table 2). In order to minimize bias due to sample preparation several methods of cooking were examined prior to organoleptic assessment. These included preparing samples by heating at $90^{\circ} \mathrm{C}$ in $\mathrm{PE} /$ PA 20/70 bags, sealed under vacuum, for 5, 10, 15, 20 and 25 minutes or by baking at $175^{\circ} \mathrm{C}$ in covered aluminum trays for 10 and 15 minutes. Drip-loss from each sample was recorded during preparation. Samples prepared at $90^{\circ} \mathrm{C}$ for 20 minutes were chosen for all sensory analyses since 
this method did not produce detectable off-odors or flavors and cooking for 20 minutes resulted in all samples being fully prepared, with a drip loss of $17-20 \%$. In contrast, cooking for 25 minutes yielded a $25 \%$ drip-loss, whereas baking in covered aluminum trays for 10 or 15 minutes led to sample drying, discoloration and production of an 'oily' odor.

\section{Sensory analyses}

A trained panel of six performed sensory analyses. Sample designation codes were randomized. A small cutlet, approximately $25 \mathrm{~g}$ wet weight, was served immediately following preparation. Smell, taste, and texture were evaluated by means of the developed sensory scheme (Table 1). An overall impression of "less acceptable" was set as a rejection point while shelf life was defined as the point where at least half of the panelists rejected the sample. Loss of prime quality was defined as the point where at least half of the panelists judged the fish "less good" (Table 1).

\section{Microbiological analyses}

Iron Agar (IA) was used for total aerobic and $\mathrm{H}_{2} \mathrm{~S}$-producing spoilage bacteria counts (Veterinaerdirektoratet 1989). Spread and pour plates were used. All tissue samples for analyses were taken between the dorsal fin and lateral line posterior to the vent. Lactic acid-forming bacteria were measured as pour plate count in nitrite actidione polymyxin agar (NAP) (Davidson and Cronin 1973), using APT agar supplemented with $1 \mathrm{ml} 100 \mathrm{ml}^{-1}$ of NAP solution (Merck KGaA, Darmstadt, Germany). For surface counts a $5 \mathrm{~cm}^{2}$ area (approximately $1 \mathrm{~mm}$ thick) of skin was used. For deep flesh counts, the surface was sterilized by heating, and a $5 \mathrm{~g}$ sample $\left(\sim 2 \mathrm{~cm}^{3}\right)$ removed, homogenized (Colworth stomacher, Seward, London, UK) in $0.9 \% \mathrm{NaCl}$ with $0.1 \%$ peptone for 2 minutes and a dilution series constructed followed by inoculation. Plates were aerobically incubated for 72 hours at $21^{\circ} \mathrm{C}$ for total and $\mathrm{H}_{2} \mathrm{~S}$-producing bacteria and for 120 hours at $21^{\circ} \mathrm{C}$ for lactic acid-forming bacteria (Veterinaerdirektoratet 1989) before counting.

\section{Chemical analyses}

All chemical analyses were performed in duplicate for each sample. Fish were filleted and homogenized in a blender. Dry matter and ash content of the fillet was determined after 24 hours at $105^{\circ} \mathrm{C}$ and $550^{\circ} \mathrm{C}$ respectively. Oil content of was determined using chloroform:methanol extraction (Bligh and Dyer 1959), and protein content (Kjeldahl-N) 
Table 1. Sensory panel scheme developed and employed for the evaluation of cooked eels. See Table 2 for detailed explanation of each of the definitions employed.

\section{Sensory evaluation of cooked eel}

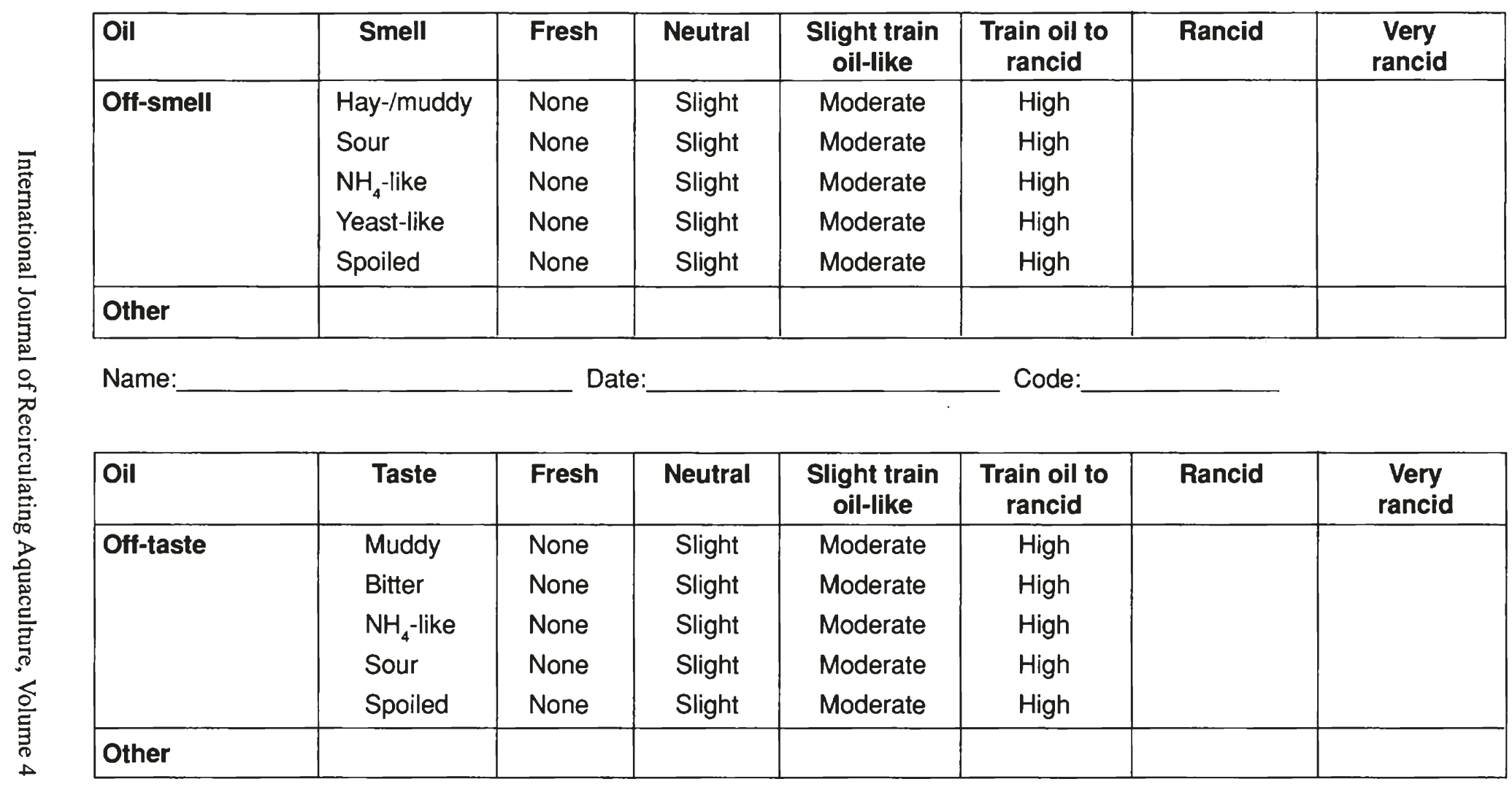

u 
Table 1. cont'd.

\begin{tabular}{|l|l|l|l|c|c|}
\hline Texture & & Fresh & Neutral & $\begin{array}{c}\text { Slight train } \\
\text { oil-like }\end{array}$ & $\begin{array}{c}\text { Train oil to } \\
\text { rancid }\end{array}$ \\
\hline & Elasticity & None & Slight & Moderate & High \\
& Firmness & None & Slight & Moderate & High \\
& Toughness & None & Slight & Moderate & High \\
& Juiciness & None & Slight & Moderate & High \\
& Grainy/grittiness & None & Slight & Moderate & High \\
& Stickiness & None & Slight & Moderate & High \\
\hline Other & \multicolumn{2}{|l}{} & & & \\
\hline
\end{tabular}

\begin{tabular}{|l|c|c|c|c|c|c|c|}
\hline $\begin{array}{l}\text { Overall } \\
\text { impression }\end{array}$ & Very good & Good & Less good & Acceptable & Less acceptable & Unacceptable & Poor \\
\hline
\end{tabular}

Comments: 


\section{Definitions and Instructions}

Smell: Smell the sample in the plastic bag immediately after opening.

- An oil smell is characterized by: fresh oil smell is pleasant, train oil-like smell is unpleasant, rancid oil smell is acrid, thick and very unpleasant.

- Hay like smell is characterized by: cut, dried grass odor

- Yeast-like smell is characterized by sickly sweet and moldy odor

- Ammonia-like smell characterized by prickly odor

- Spoiled smell, characterized by a stuffy to rotten and unpleasant odor

Taste: Before tasting, the skin and/or sub-dermal layer is removed and a sample of white dorsal flesh used.

- Oil taste characterized by same parameters as for smell

- Muddy off-taste, recognized 5-10 seconds after the sample is placed in the mouth

- Ammonia-like taste detected as a very prickly feeling

- Spoiled taste is characterized by a tainted to rotten and unpleasant flavor

Texture: The texture is defined for the individual parameters. A sample of white dorsal flesh is used.

- Elasticity is described immediately after the sample is placed into the mouth. The flesh is considered elastic when it "bounds" back after one or two chews.

- Firmness is when the flesh feels cohesive after several chews.

- Toughness is when the flesh is continuously tough after a minimum of 5 chews (rubber like).

- Juiciness is when the flesh maintains moisture, thus not drying after 5 chcws.

- Graininess/grittiness is when the flesh feels mushy and incohesive

- Stickiness is when the flesh sticks to the teeth and a resistance is experienced when chewing after $4-5$ chews.

Overall impression: This is judged as the impression in comparison to other eels served during training at this and earlier sessions. Impression does not depend upon personal affinity for eel. When all parameters are good, the fish is judged as being very good. Slight off tastes reduce overall impression to less good, etc.

Comment: Describe why the fish has received the respective score in overall impression; e.g., if a muddy taste results in a lower score.

\section{Level of score:}

- None: is where the stated characteristics are undetectable.

- Slight: is where the respective characteristics can be traced but not in a pronounced manner

- Moderate: is where the presence of a characteristic is unequivocal

- High is where the characteristic is strongly present

Table 2. Instructional sheet employed during the sensorial evaluation of cooked eels, providing definitions and instructions to sensory panelists. 
according to AOAC (1984). TBA was determined as described by Vyncke (1975) with the following modification: a $15 \mathrm{~g}$ sample was mixed in $40 \mathrm{ml}$ trichloracetic acid solution and incubated for 24 hours at $21^{\circ} \mathrm{C}$. Absorbency was read at $530 \mathrm{~nm}$. Drip-loss was measured as the difference between initial weight and actual weight of the eel. TVB-N, TMA-O and TMA were determined using Conway micro diffusion chambers (Conway and Byrne 1933) with 0.025 N HCL in the inner ring and saturated $\mathrm{K}_{2} \mathrm{SO}_{4}$ in the outer ring. Volatile bases were extracted from the sample in a 1:4 mixture by weight of homogenized fish flesh and distilled water, $\mathrm{pH}$ adjusted to 5.2 , and heated to $70^{\circ} \mathrm{C}$ for 2 minutes. $\mathrm{pH}$ was measured in the mixture at $25^{\circ} \mathrm{C}$ prior to adjustment with $\mathrm{HCl}$. Nucleotide breakdown was measured as a $\mathrm{k}_{1}$ value (Gill 1992) using Fresh tester FTP II sticks (Transia, EAC Corporation, Japan). All chemicals used were of analytical grade, obtained through Merck, except substrates for IA plates (Difco, Detroit, MI, USA).

\section{Data analyses}

Chemical and microbial data were analyzed statistically using two way ANOVA, and pairwise Student Newman-Keul comparison tests were used to test for differences between groups. Correlations between overall impression and TBA $/ \mathrm{k}_{1}$ values were examined using least square regression. Data from the sensory panel were analyzed by means of multivariate calibration using UNSCRAMBLER ${ }^{\circledR}$ (Camo, Trondheim, Norway). Each parameter on the sensory sheets was given a score, corresponding to sensory score specified the level detected, e.g. $0=$ none, 1 = slight, 2 = moderate, $3=$ high (Figure 1 ). Correlation coefficients between overall impression (Y-matrix) and various groups (X-matrix) were assessed using a Partial Least Square model (PLS1). Resulting weighting coefficients $\left(\mathrm{B}_{\mathrm{W}}\right.$-matrix) display the significance of each examined parameter in describing overall impression. Thus, higher absolute value indicates the most important parameters. Positive weighting coefficients reveal a positive correlation between the parameter and overall impression, whereas negative coefficients infer the opposite. Comparison of treatments was undertaken using PLS2 models, correlating sensory characteristics (X-matrix) to overall impression ( $\mathrm{Y}$ matrix). Dummy variables were included in the Y-matrix (as an identity matrix), with each dummy vector given a value 1 for one respective code at a given time, while remaining groups were allocated value 0 in the same vector. Resulting loading plots for the dummy variables revealed

54 International Journal of Recirculating Aquaculture, Volume 4 
differences between groups related to sensory characteristics. All raw data were weighted by STDEV ${ }^{-1}$ prior to PLS modeling.

\section{RESULTS}

The average oil content of eel was $39.1 \%$ ( $n=8$; range: $31-47 \%$ ), whereas dry matter was $47.8 \%$ ( $n=8$; range: $43.7-66.6 \%)$. Protein and ash content were $12.1 \%$ ( $n=8$; range $11.6-13.1 \%)$, and $0.69 \%$ ( $n=8$; range $0.64-0.73 \%$ ) respectively. TMA-O and TMA in eels stored for 0 or 13

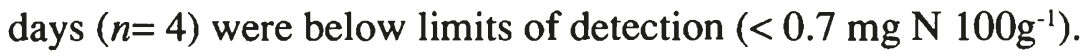

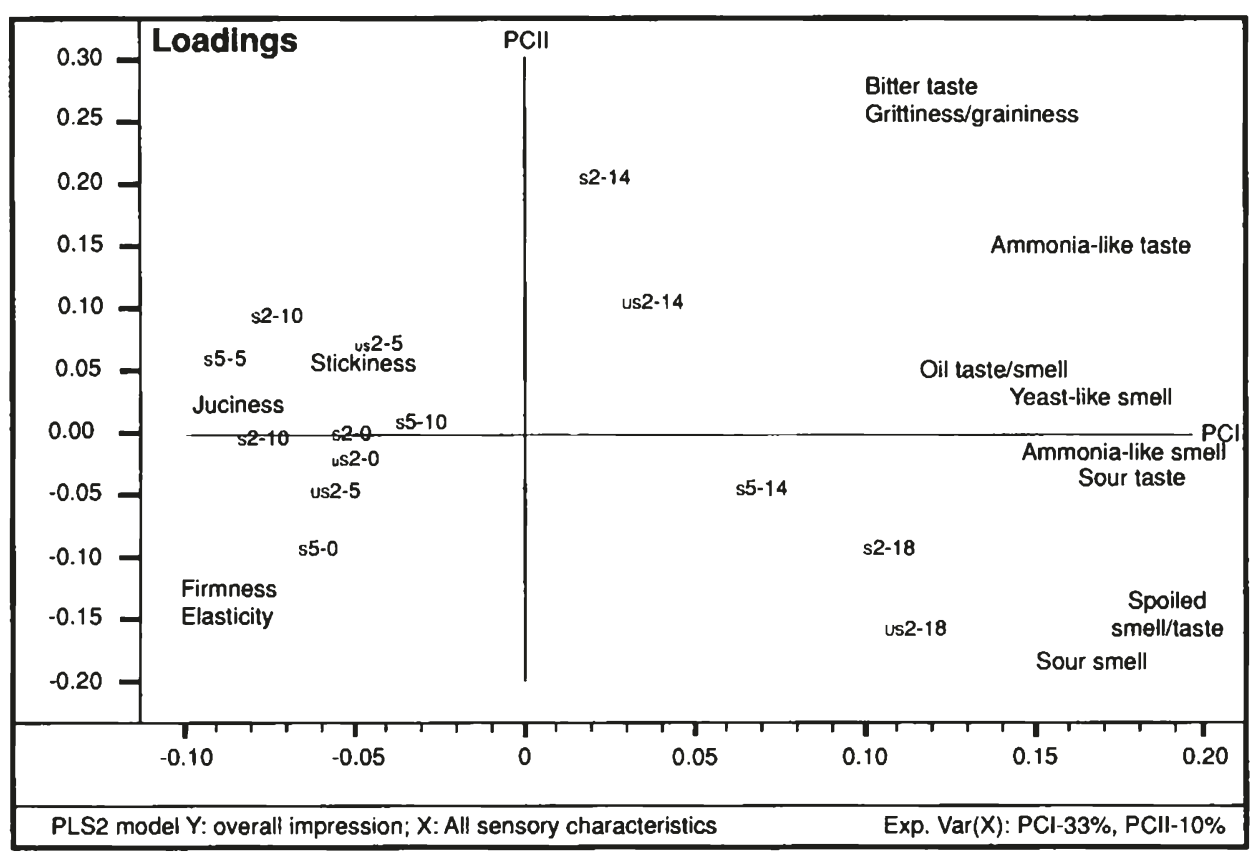

Figure 1. Trends in sensory characteristics among groups and days shown by PLS2 plots. us2: unskinned fish stored at $2{ }^{\circ} \mathrm{C}$; us 5 : unskinned fish stored at $5{ }^{\circ} \mathrm{C} ; \mathrm{s} 2$ : skinned fish stored at $2^{\circ} \mathrm{C} ; \mathrm{s} 5$ : skinned fish stored at $5^{\circ} \mathrm{C}$. The hyphenated number following each point represents the number of days the sample was stored. 


\section{Sensory changes and shelf life}

The effects of temperature and skinning upon shelf life, maintenance of quality, and overall impression are summarized in Table 3. Prime quality was maintained for a period of 5 days irrespective of storage temperature or the presence of skin. Shelf life was extended for both skinned and unskinned eels at the lower temperature employed (Table 3). No differences in overall impression were recorded between treatments for the first 10 days of storage. By day 14 however, diffcrences $(P<0.05)$ in overall impression became apparent for both temperatures evaluated and for skinned and unskinned fish. By day 18 of the trial, eel stored at $5^{\circ} \mathrm{C}$ were considered unacceptable. Fish stored at $2^{\circ} \mathrm{C}$ were considered acceptable but expressed a significant decline in overall impression when compared against all other sampling points (Table 3). PLS2 plots (Figure 1) revealed trends in changes to sensory characteristics for the eels during storage, with PCI explaining 33\% and PCII 10\% of the variance. Table 4 notes weightings of the sensory characteristics examined. The first signs of spoilage were changes in the smell of oil together with a train oil-like taste. Texture characteristics changed only slightly during the first 10 days of storage with the sensory panel being unable to determine the presence of off-flavors/odors. Textural changes and off-odors/flavors became prominent from day 10 onwards, mainly being expressed in unskinned eels as a loss of firmness, development of a sticky flesh structure and increased graininess/grittiness. The sensory characteristics changed more rapidly in fish stored at $5^{\circ} \mathrm{C}$ than those stored at $2^{\circ} \mathrm{C}$, with differences being apparent at day 14 . This resulted in eels stored at $2^{\circ} \mathrm{C}$ having a longer shelf life than those stored at $5^{\circ} \mathrm{C}$. The impact of skinning also became apparent following 10-14 days of storage, with skinned eels expressing unfavorable organoleptic characteristics when compared against unskinned samples. A muddy smell/taste was detected in some eels and panelists commented that this was unappealing. However, since this flavor did not change over time, no correlation was found with spoilage or degradation.

\section{Chemical analyses}

Significant $(\mathrm{P}<0.05)$ increases in TVB-N (Figure 2) were observed throughout storage, with eels held at $5^{\circ} \mathrm{C}$ expressing higher levels $(\mathrm{P}<0.05)$ than fish maintained at $2^{\circ} \mathrm{C}$ from day 10 onwards. Unskinned animals exhibited elevated levels of TVB-N $(\mathrm{P}<0.05)$ when compared to skinned fish (Figure 2). As for TVB-N, the degree of sample lipid 


\begin{tabular}{|l|c|c|c|c|}
\hline & \multicolumn{2}{|c|}{$2^{\circ} \mathbf{C}$} & \multicolumn{2}{c|}{$5^{\circ} \mathbf{C}$} \\
\hline & Skinned & Unskinned & Skinned & Unskinned \\
\hline Prime quality (days) & 5 & 5 & 5 & 5 \\
Range & $(0-5)$ & $(0-5)$ & $(0-5)$ & $(0-5)$ \\
Shelf life (days) & 18 & 18 & 14 & 14 \\
Range & $(14-18)$ & $(14-18)$ & $(10-14)$ & $(10-14)$ \\
& & & & \\
Overall impression ${ }^{\star}:$ & & & & \\
\hline Day 0 & $1.20^{\mathrm{a}}$ & $1.20^{\mathrm{a}}$ & $1.80^{\mathrm{a}}$ & $1.80^{\mathrm{a}}$ \\
Day 5 & $1.60^{\mathrm{a}}$ & $2.00^{\mathrm{a}}$ & $1.40^{\mathrm{a}}$ & $2.20^{\mathrm{a}}$ \\
Day 10 & $1.40^{\mathrm{a}}$ & $1.80^{\mathrm{a}}$ & $2.40^{\mathrm{a}}$ & $2.20^{\mathrm{a}}$ \\
Day 14 & $3.40^{\mathrm{b}}$ & $3.40^{\mathrm{b}}$ & $4.00^{\mathrm{b}}$ & $5.20^{\mathrm{b}}$ \\
Day 18 & $5.60^{\mathrm{c}}$ & $5.60^{\mathrm{c}}$ & & \\
\hline
\end{tabular}

$* S E M=0.52$

Table 3. Maintenance of prime quality, shelf life and changes in overall impression $(0=$ very good; $6=$ poor) of skinned and unskinned European eels $(n=5)$ stored at $2{ }^{\circ} \mathrm{C}$ and $5{ }^{\circ} \mathrm{C}$. Similar superscripts in the same column indicate no significant difference $(P>0.05)$ between. No differences were found between groups in terms of quality, shelf life and changes in overall impression.

oxidation (TBA) also increased throughout the study period (Figure 3), with differences $(\mathrm{P}<0.05)$ in TBA presence being apparent by day 5 between skinned and unskinned eel maintained at the same temperature. TBA was the most suitable variable for predicting overall impression (PLS1 modeling between overall impression and chemical/microbial analysis) with strong polynomial correlation $\left(\mathrm{P}<0.0001 ; \mathrm{R}^{2}=0.75\right)$ being determined.

The response of flesh $\mathrm{pH}$ to different storage temperatures and the presence of skin is summarized in Figure 4. Skinned eels exhibited a biphasic increase in flesh $\mathrm{pH}$, with rapid initial increases $(\mathrm{P}<0.05)$ in $\mathrm{pH}$, when compared against unskinned eels, followed by a plateau at approximately $\mathrm{pH} 6.75$ to trial termination. In contrast, unskinned eels expressed a continuous increase $(\mathrm{P}<0.05)$ in $\mathrm{pH}$ throughout the experiment, with final values being recorded as approximately $\mathrm{pH} 7.5$. 


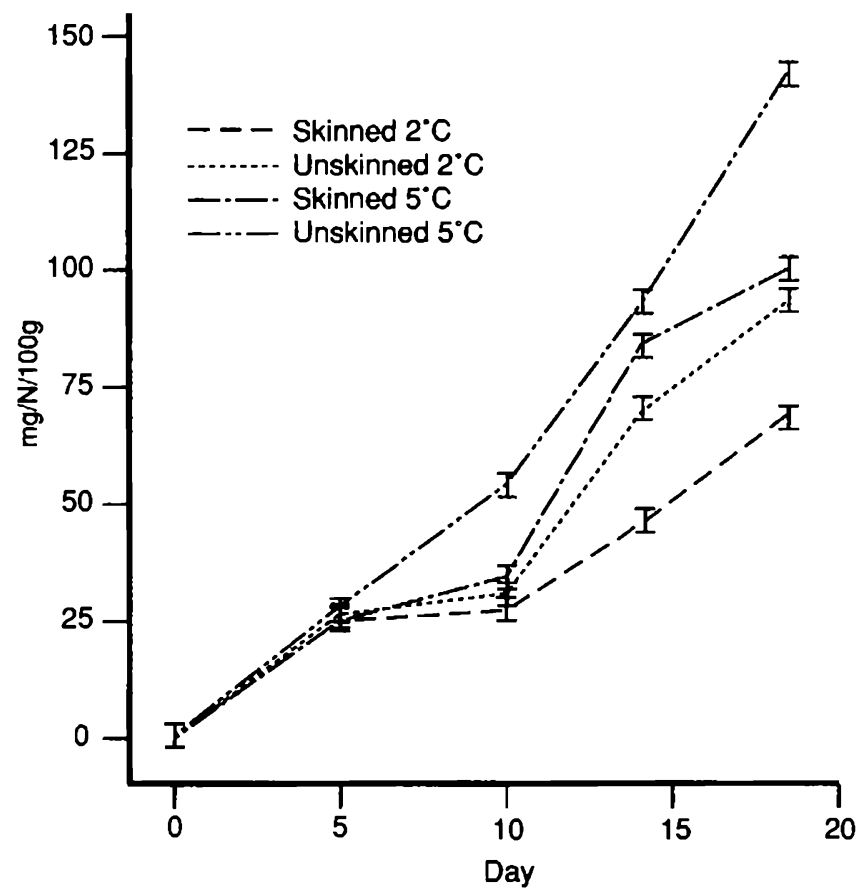

Figure 2. Development of Total Volatile Bases-Nitrogen (TVB-N) in skinned and unskinned European eel stored at $2^{\circ} \mathrm{C}$ or $5^{\circ} \mathrm{C}$. Vertical bars represent $\pm S E M(n=2)$.

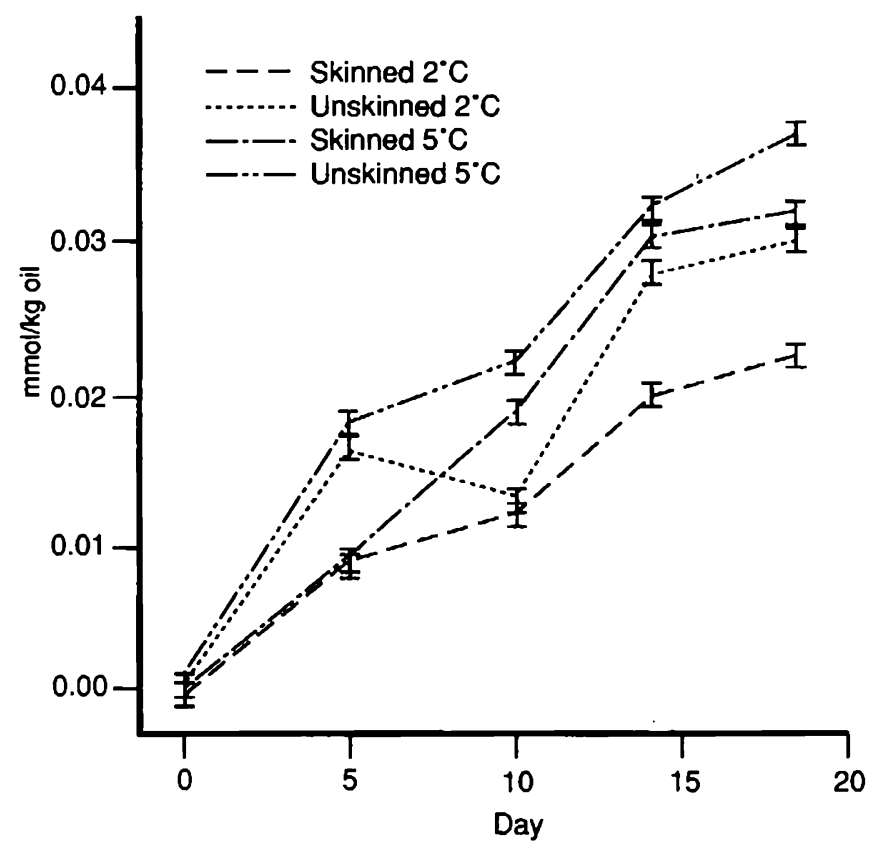

Figure 3. Lipid oxidation (TBA) of skinned and unskinned European eel stored at $2^{\circ} \mathrm{C}$ or $5^{\circ} \mathrm{C}$. Vertical bars represent $\pm S E M(n=2)$.

58 International Journal of Recirculating Aquaculture, Volume 4 
Measurement of nucleotide breakdown in skinned eels stored at $2^{\circ} \mathrm{C}$ (Figure 5) revealed a significant increase $(\mathrm{P}<0.05)$ over time with $\mathrm{k}_{1}=51.25$ at rejection (day 18). The $\mathrm{k}_{1}$-value demonstrated a significant $\left(\mathrm{P}<0.0001 ; \mathrm{R}^{2}=0.72\right)$ polynomial correlation with overall impression.

\section{Microbiological analyses}

Spread plates $(n=160)$ had significantly $(\mathrm{P}<0.05)$ higher bacterial counts than pour plates: differences were usually $40-50 \%$ higher for the spread plates but extremes of up to $90 \%$ were seen. Hence, only results obtained with spread plates were considered in later analyses. Initially $10^{4}-10^{5}$ bacteria $\mathrm{cm}^{-2}$ were present on the surface of the eels, with no $\mathrm{H}_{2} \mathrm{~S}$-producing spoilage bacteria being detected (Table 5). Bacteria developed exponentially $(\mathrm{P}<0.05)$ during the first 10 days of storage, followed by a stationary phase, which lasted for the remainder of the trial. Bacterial counts in eels stored at $5^{\circ} \mathrm{C}$ increased more rapidly than those stored at $2^{\circ} \mathrm{C}(\mathrm{P}<0.05)$, and unskinned fish had a more rapid increase in bacterial numbers than skinned eels (Table 5).

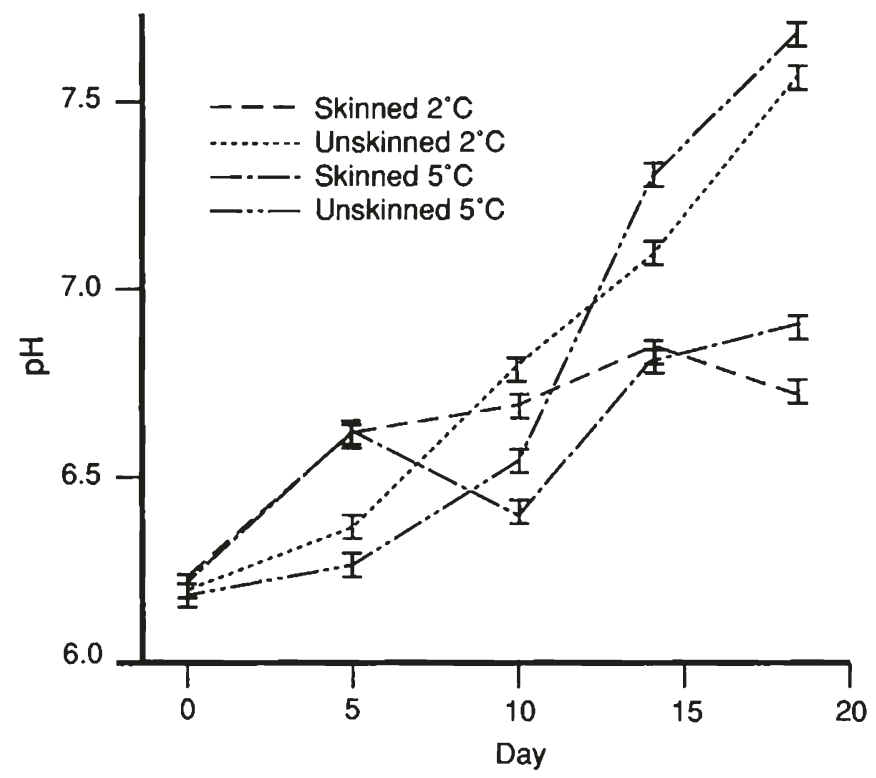

Figure 4. Changes in flesh pH of skinned and unskinned European eel stored at $2^{\circ} \mathrm{C}$ or $5^{\circ} \mathrm{C}$. Vertical bars represent $\pm S E M(n=2)$. 


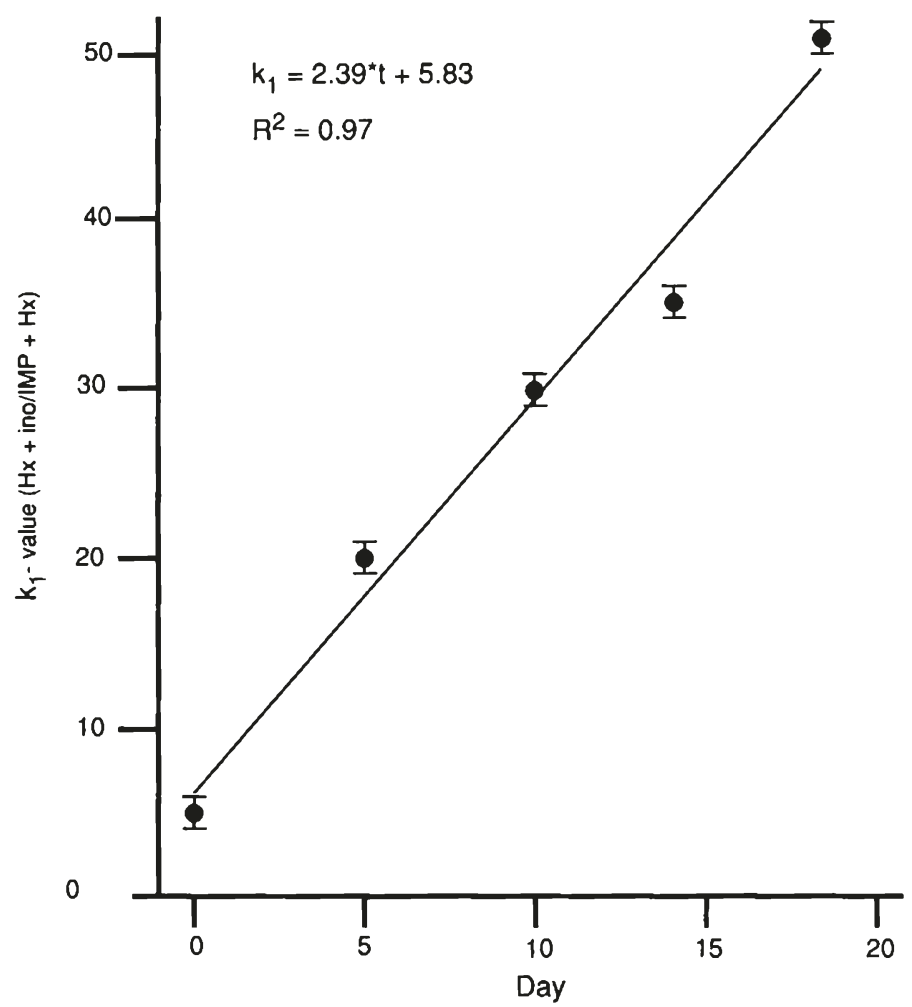

Figure 5. Nucleotide breakdown $\left(k_{1}\right)$ in skinned eels stored at $2{ }^{\circ} \mathrm{C}$. IMP was the level of inosine monophosphate, $H x$ the level of hypoxanthine, and Ino the level of inosine. Vertical bars represent $\pm S E M(n=2)$

\section{DISCUSSION}

The eels used in the present study were raised under intensive recirculating conditions and expressed fat content 2.5 - 3.5 times higher than those reported for wild fish (Rehbein and Hinz 1983, Lie et al. 1990) and 1.0 - 1.8 times those reported previously for farmed eels (Lie et al. 1990, Gallego et al. 1993). These differences might be due to feeding: the eels used in the present investigations had been fed a highenergy diet (23\% lipid) and body fat content is influenced by dietary fat level (Coello et al. 1999, Rasmussen et al. 2000). The shelf life determined for fresh farmed chilled eels was in general agreement with that reported by Rehbein and Hinz (1983) for raw, wild eels. The latter authors indicated a shelf life of 16-20 days for fish stored at $0^{\circ} \mathrm{C}$. Thus, it appears that farmed eels, even with a 3-fold higher fat content, maintain quality for as long as wild animals when taking storage temperature differences into account. In the present study, temperature had a greater

60 International Journal of Recirculating Aquaculture, Volume 4 


\begin{tabular}{|c|c|c|}
\hline \multicolumn{2}{|c|}{ Correlation coefficient $\mathbf{R}^{2}$} & 0.7852 \\
\hline \multicolumn{2}{|c|}{ Sensory variables } & Parameter weight \\
\hline \multirow[t]{6}{*}{ Smell } & Oil & 0.2265 \\
\hline & Muddy & 0.0704 \\
\hline & Sour & 0.0872 \\
\hline & Ammonia-like & 0.0367 \\
\hline & Fermented & -0.0947 \\
\hline & Spoiled & 0.6243 \\
\hline \multirow[t]{6}{*}{ Taste } & Oil & 0.3381 \\
\hline & Muddy & -0.0425 \\
\hline & Bitter & 0.0477 \\
\hline & Ammonia-like & 0.1697 \\
\hline & Sour & 0.0005 \\
\hline & Spoiled & 0.5249 \\
\hline \multirow[t]{6}{*}{ Texture } & Elasticity & -0.0750 \\
\hline & Firmness & -0.3424 \\
\hline & Toughness & 0.0943 \\
\hline & Juiciness & -0.0346 \\
\hline & Grainy/gritty & 0.4957 \\
\hline & Sticky & 0.2423 \\
\hline
\end{tabular}

Table 4. Correlation between overall impression and sensory variables (mean values, $n=20$ ) for chill stored eels (PLSI model). Parameter weight indicates importance of sensory attributes. 


\begin{tabular}{|c|c|c|c|c|c|c|c|c|}
\hline \multicolumn{5}{|c|}{ Total surface bacterial counts ${ }^{*}$} & \multicolumn{4}{|c|}{ Total deep flesh bacterial counts ${ }^{\star \star}$} \\
\hline Day & $2^{\prime} \mathrm{CS}$ & $2^{\circ} \mathrm{CUS}$ & $5^{\circ} \mathrm{CS}$ & $5^{\circ} \mathrm{C}$ US & $2^{\circ} \mathrm{CS}$ & $2^{\circ} \mathrm{C}$ US & $5^{\circ} \mathrm{CS}$ & $5^{\circ} \mathrm{C}$ US \\
\hline 0 & $5.35_{A}^{a}$ & $4.42_{A}^{b}$ & $5.35_{A}^{a}$ & $4.42_{A}^{b}$ & $N D_{A}^{a}$ & $\mathrm{ND}_{\mathrm{A}}^{\mathrm{a}}$ & $\mathrm{ND}_{\mathrm{A}}^{\mathrm{a}}$ & $\mathrm{ND}_{\mathrm{A}}^{\mathrm{a}}$ \\
\hline 5 & $6.46_{B}^{a}$ & $6.93_{\mathrm{B}}^{\mathrm{b}}$ & $7.45_{B}^{c}$ & $7.85_{B}^{d}$ & $3.45_{8}{ }^{a}$ & $4.37_{B}^{b}$ & $4.40_{\mathrm{B}}^{\mathrm{b}}$ & $5.3_{B}^{c}$ \\
\hline 10 & $8.92_{c}^{a}$ & $9.28_{C}^{b, c}$ & $9.10_{C}^{a . b}$ & $9.36_{c}^{c}$ & $6.48_{C}^{a}$ & $7.01_{c}^{b}$ & $7.11_{C}^{b . c}$ & $7.43_{\mathrm{C}}^{\mathrm{c}}$ \\
\hline 14 & $9.54_{D}^{a . c}$ & $9.68_{D}^{a}$ & $9.33_{\mathrm{C}}^{\mathrm{b}}$ & $9.44_{c}^{a, b, c}$ & $7.32_{\mathrm{D}}^{\mathrm{a}}$ & $8.07_{D}^{b}$ & $6.93_{c}^{c}$ & $6.93_{D}^{c}$ \\
\hline 18 & $9.90_{E}^{a}$ & $9.49_{C, D}{ }^{b}$ & $9.23_{\mathrm{CD}}^{\mathrm{c}}$ & $9.89_{D}^{a}$ & $6.58_{C}^{a}$ & $7.10_{C}^{\circ}$ & $7.09_{C}^{b}$ & $7.26_{\mathrm{CD}}^{\mathrm{b}}$ \\
\hline \multicolumn{5}{|c|}{$\begin{array}{c}\mathrm{H}_{2} \text { S-producing bacterial counts } \\
\text { (surface) }\end{array}$} & \multicolumn{4}{|c|}{$\begin{array}{l}\mathrm{H}_{2} \text { S-producing bacterial counts } \\
\text { (deep flesh) })^{\star \star \star}\end{array}$} \\
\hline Day & $2^{\circ} \mathrm{CS}$ & $2^{\circ} \mathrm{CUS}$ & $5^{\circ} \mathrm{CS}$ & $5^{\circ} \mathrm{C}$ US & $2^{\circ} \mathrm{CS}$ & $2^{\circ} \mathrm{CUS}$ & $5^{\circ} \mathrm{CS}$ & $5^{\circ} \mathrm{C}$ US \\
\hline 0 & $\mathrm{ND}_{\mathrm{A}}^{\mathrm{a}}$ & $\mathrm{ND}_{\mathrm{A}}^{\mathrm{a}}$ & $\mathrm{ND}_{\mathrm{A}}^{\mathrm{a}}$ & $N D_{A}{ }^{a}$ & $\mathrm{ND}_{\mathrm{A}}{ }^{\mathrm{a}}$ & $\mathrm{ND}_{\mathrm{A}}^{\mathrm{a}}$ & $\mathrm{ND}_{\mathrm{A}}^{\mathrm{a}}$ & $\mathrm{ND}_{\mathrm{A}}^{\mathrm{a}}$ \\
\hline 5 & $3.83_{\mathrm{B}}^{\mathrm{a}}$ & $4.77_{B}^{b}$ & $6.06_{8}^{c}$ & $7.14_{B}^{d}$ & $1.00_{B}^{a}$ & $2.74_{B}^{b}$ & $3.37_{B}^{c}$ & $4.32_{B}^{d}$ \\
\hline 10 & $7.32_{C}^{a}$ & $8.05_{C}^{b}$ & $7.40_{C}^{a}$ & $8.18_{C}^{b}$ & $4.85_{c}^{a}$ & $5.64_{c}^{\circ}$ & $5.73_{C}^{b}$ & $6.24{ }_{C}^{c}$ \\
\hline 14 & $7.84_{0}^{a}$ & $8.28_{C, D}^{b}$ & $7.84_{D}^{a}$ & $8.70_{D}^{C}$ & $5.34_{D}^{b}$ & $6.20_{c}^{c}$ & $5.92_{C}^{c}$ & $6.32_{C}^{b}$ \\
\hline 18 & $7.98_{D}^{a}$ & $8.40_{D}^{b}$ & $7.19_{E}^{c}$ & $8.46_{E}^{b}$ & $5.81_{c}^{b}$ & $5.33_{D}^{b}$ & $6.51_{D}^{b}$ & $6.06_{C}^{c}$ \\
\hline
\end{tabular}

- SEM $=0.05$

$\because \mathrm{SEM}=0.08$

$\cdots$ SEM $=0.09$

Table 5. Development of total surface $\left(\log \mathrm{CFU} / \mathrm{cm}^{2}\right)$, deep flesh $(\log \mathrm{CFU} / \mathrm{g})$, and $\mathrm{H}_{2} \mathrm{~S}$ producing bacteria in skinned (S) and unskinned (US) eels held at $2^{\circ} \mathrm{C}$ and $5^{\circ} \mathrm{C}(n=2)$. $N D=$ not detectable. Values in the same column exhibiting different subscripts were significantly different $(P<0.05)$. Similar superscripts in the same row, for each of the bacterial counts, indicate no difference $(P>0.05)$ between counts.

influence over organoleptically detectable spoilage of eel than did skinning.

Organoleptic, microbiological and biochemical indices were all affected by temperature: more rapid spoilage was observed at high temperature, and this increased colonization by $\mathrm{H}_{2} \mathrm{~S}$-producing bacteria (Table 5), elevated TBA/TVB-N (Figs. 2 and 3) and enhanced rejection by the sensory panel (Table 3 ). All the preceding factors are welldocumented occurrences during seafood spoilage (see Sikorski et al. 1990, Huss 1995, Bremner 2002). Skinning was correlated with lower bacterial loading, decreased lipid oxidation and retarded TVB-N appearance profiles. Unskinned fish initially expressed lower flesh $\mathrm{pH}$ values than skinned eel, which likely resulted due to anaerobic 
conditions restraining the breakdown of muscle lactic acid (Huss 1995). In the present study, a change in flesh $\mathrm{pH}$ (from 6.2-7.6) was associated with alterations in flesh firmness and the onset of a gritty/grainy texture. A lowering of flesh $\mathrm{pH}$ is generally associated with a weakening of structural elements by different endogenous muscle peptidases (calpain/ cathepsin) that degrade myofibrillar components and its breakdown products (see Dransfield 1994, Davis et al. 1994).

Some eel samples expressed a muddy flavor, which was classed by the sensory panel as an unappetizing feature, decreasing overall impression. In an attempt to clear this off-flavor, eels were starved and purged in fresh water for a week. In catfish and other species, this period of time is generally considered as adequate for the purpose (Heikes 1993, Persson 1995). However, with eel, the variable muddy flavor was maintained even after purging, which may be one reason underlying the differences in acceptability noted for some of the fresh eels on day 0 of the study. Thus a longer period of starvation and purging may be necessary to gain excellent initial quality ratings by sensory panels, although further investigations in this field should be undertaken to establish optimal conditions for purging.

The existence of discrete connections between sensory, microbial and or biochemical indices are of high importance, since these may assist in constructing quality grading systems for industrial application. From the results presented, TBA and or $k_{1}$ values may be useful as estimators of chilled stored eel quality. The $\mathrm{k}_{1}$ value increased linearly over time, with a level of approximately 50 at the point of rejection. These data correlate well with that presented for yellowtail (Sakaguchi and Koike 1992), within the first 10 days of chill storage but differ from the findings of Rodriguez et al (1999) with refrigerated $\left(4-5^{\circ} \mathrm{C}\right)$ rainbow trout following 12 days storage. The latter authors indicated a $k_{1}$ value of 70 on the day of marginal acceptability. From the results presented, farmed unskinned eels held at $2^{\circ} \mathrm{C}$, provided the most favorable storage conditions, with a shelf life of 14-18 days. However, prime quality was lost after 5 days.

\section{ACKNOWLEDGEMENT}

The authors wish to thank members of the sensory panel for participating in the study. 
Association of Analytical Communities (AOAC) 1984. Official Methods of Analysis, 14th Edition. AOAC, Arlington, VA, USA.

Bligh, E. G., Dyer, W. J. A Rapid Method of Total Lipid Extraction and Purification. Canadian Journal of Biochemistry and Physiology 1959. 37, 911-917.

Bremner, H.A. (Ed.) 2002. Safety and Quality Issues in Fish Processing. Woodhead Publishing Ltd., Abington Hall, Abington, Cambridge, UK.

Bovbjerg, P. Eel Culture Trends in Europe. Fisheries Bulletin of the Marine Institute (Dublin) 1999. 17, 35-37.

Byrne, B. Eel Products and Markets: An Overview of the Market for Eel in Germany. Fisheries Bulletin of the Marine Institute (Dublin) 1999. $17,39-41$.

Coello, M. T., Sanchez, M. -J., Vicario, I. M., Heredia, F. J., Martin, M. Assessing Acceptability of Eel (Anguilla anguilla) Fed Three Different Diets. Journal of the Science of Food and Agriculture 1999. 79, 20872093.

Conway, E.J., Byrne, A. An Absorption Apparatus for the Micro-Determination of Certain Volatile Substances - I: The Micro-Determination of Ammonia. Biochemical Journal 1933. 27, 419-429.

Davidson, C. M., Cronin, F. Medium for the Selective Enumeration of Lactic Acid Bacteria from Food. Applied Microbiology. 1973. 26, 439440.

Davis, J. R., Ledward, D. A., Bardsley-Ronald, G., Poulter, G. Species Dependence of Fish Myosin Stability to Heat and Frozen Storage. International Journal of Food Science and Technology 1994. 29, 287301.

Dransfield, E. Modeling Post-Mortem Tenderisation: vs. Inactivation of Calpains. Meat Science 1994. 37, 391-409.

64 International Journal of Recirculating Aquaculture, Volume 4 
Federation of European Aquaculture Producers (FEAP). European Eel

Production. http://www.feap.org/eels.html. 2002.

Fransu, L. World Eel Market Review. INFOFISH International 1989. 6, 18-22.

Gallego, G. G., Hidalgo, M. C., Suarez, M. D., Sanz, A., Higuera, M.

Feeding of the European Eel Anguilla anguilla. II Influence of Dietary Lipid Level. Comparative Biochemistry and Physiology 1993. 105A, 171-175.

Gill, T. A. Biochemical and Chemical Studies on Seafood Quality. In Quality Assurance in the Fish Industry. Huss, H. H. (Ed.). 1992. Elsevier Science Publishers B.V., Amsterdam, Holland.

Globefish. The Markets for Freshwater Fish in Europe. Globefish Research Programme 1998. 49.

Heikes, D. In-Pond Purging for Catfish with Off-Flavor. Aquaculture Magazine 1993, July/August, 28-32.

Heinsbroek, L. T. N. A Review of Eel Culture in Japan and Europe. Aquaculture and Fisheries Management 1991. 22, 57-72.

Hultin, H. O. Biochemical Deterioration of Fish Muscle. In Quality Assurance in the Fish Industry. Huss, H. H. (Ed.). 1992. Elsevier Science Publishers B.V., Amsterdam, Holland.

Huss, H. H. 1995. Quality and Quality Changes in Fresh Fish. FAO, Rome, Italy.

Lie, Ø., Hemre, G. I., Lambertsen, G. A Comparison of the Composition of Cultured and Wild Caught European Eel (Anguilla anguilla), Particularly Regarding Lipids. Fiskeridirektoratet Skr., Series Ernœering 1990. III, 3-11.

Rehbein, V. H., Hinz, A. Vergleich Zwischen Physikalischen und Chemischen Metoden zur Bestimmung des Verderbs Unbehandelter oder Entschleimter aal bei Eislagerung. Archiv fûr Lebensmittelhygiene 1983. 34, 53-80. 
Persson, P. E. 19th Century and Early 20th Century Studies on Aquatic Off-Flavours - A Historical Review. Water Science and Technology 1995. 31, 9-13.

Rasmussen, R. S., Ostenfeld, T. H., McLean, E. Growth and Feed Utilisation of Rainbow Trout Subjected to Changes in Feed Lipid Concentrations. Aquaculture International 2000. 8, 531-542.

Rodriguez, C. J., Besterio, I., Pascual, C. Biochemical Changes in Freshwater Rainbow Trout (Oncorhynchus mykiss) During Chilled Storage. Journal of the Science of Food and Agriculture 1999. 79, 1473-1480.

Sakaguchi, M., Koike, A. Freshness Assessment of Fish Using the Tory Meter and K-Value. In Quality Assurance in the Fish Industry. Huss, H. H. (Ed.). 1992. Elsevier Science Publishers, Amsterdam, Holland.

Sikorski, E. Z., Kolawski, A., Pan, B. S. Post Harvest Biochemical and Microbial Changes. In Seafood: Resources, Nutritional Composition and Preservation Sikorski, E. Z. (Ed.). 1990. CRC Press, Inc. Boca Raton, Florida, USA.

Veterinærdirektoratet, Cirkulære om mikrobiologiske unders $\emptyset$ gelser af levnedsmidler. 1989. Veterinærdirektoratet, Copenhagen, Denmark.

Vyncke, W. Evaluation of the Direct Thiobarbituric Acid Extraction Method for Determining Oxidative Rancididy in Mackerel (Scomber scombrus L.). Fette, Seifen, Anstrichmittel 1995. 77, 239-240.

66 International Journal of Recirculating Aquaculture, Volume 4 